\title{
The Role of Financial Inclusion in Improving Community Welfare: A Study on Cooperative Business
}

\author{
Richy Wijaya ${ }^{1}$, Hartini, Farah Margaretha ${ }^{2}$ \\ \{richy.wijaya@trisakti.ac.id ${ }^{1}$ \} \\ Faculty of Economics and Business, Universitas Trisakti
}

\begin{abstract}
Financial inclusion is an important financial intervention strategy for business entities, including cooperative businesses. This research examined the role of financial inclusion in improving community welfare through saving and loan cooperatives and the effect of education level as a moderating variable. The study was correlational using a hypothesis testing method. Primary data were collected through questionnaires distributed to saving and loan cooperative members in Jakarta and its surrounding areas. This study involved 139 respondents chosen purposively: cooperative members and at least graduated from high schools. The analysis employed Structural Equation Modeling (SEM). Findings show that financial inclusion plays a significant role in reducing poverty, with or without being moderated by the education level only on the usage dimension. On the other hand, financial inclusion is not proven to significantly reduce poverty on access and service dimensions.
\end{abstract}

Keywords: Financial Inclusion; Access; Usage; Service; Poverty Level

\section{Introduction}

\subsection{Background}

Economic growth in Indonesia can be driven by increasing financial inclusion, which plays a key role in developing an efficient financial infrastructure. A healthy financial system can help a country's economic growth. One of the indicators to determine the increased penetration of financial inclusion is the decline in the number of people having no account of formal financial services. In $2014,41 \%$ of Indonesia's population did not have such an account, which decreased by $5 \%$ in 2017 . This data shows that the implementation of the national financial inclusion strategy since 2010 has made significant progress.

Financial inclusion is one way to improve community welfare through easy access and use of products or services in various financial systems, including savings, credits, insurances, payments, and remittances for people who are abroad. Financial inclusion is one of the intervention strategies in financial matters [1]. In relation to finance and development, this theory also explains the access and use of financial services, either individually or by companies, to overcome income inequality and market scarcity and achieve broader economic growth [2]. The inability of people to voluntarily or unconsciously access financial services has been identified as a major obstacle to development in the socio-economic environment of 
a region [3]. The empirical study show that understanding and skill in personal finance increases financial inclusion at Bogor Regency.

Financial inclusion through cooperatives can reduce poverty and improve socioeconomic conditions from the lowest poverty level. In 2014, the number of poor people in Indonesia was $27.73 \%$, and it decreased to $9.41 \%$ in 2019 . The decision to invest in cooperative infrastructure can also be seen as allocating resources between cooperatives and cooperative members. Analyzing the cooperative's decision to distribute cash or keep funds is done by using a two-period portfolio model because revolving equity modeling is very complex. They exclude the more common practice of retaining funds as allocated revolving capital.

\subsection{Research Problems}

The research problems are as follows:

a. Does financial inclusion affect the level of community welfare through cooperatives?

b. Does education moderate the effect of financial inclusion on community welfare through cooperatives?

\subsection{Research Purposes}

Based on the problem formulation above, the objectives for this research are:

a. To analyze the effect of financial inclusion on community welfare through cooperatives.

b. To analyze the role of education as a moderating variable on the effect of financial inclusion on community welfare through cooperatives.

\section{Literature Review}

\subsection{Financial Inclusion}

People are considered to be poor when their economic situation is below the average standard of living in society. While absolute poverty is seen as easy to overcome, relative poverty is persistent and systemic and is often viewed in the context of mitigation. The perspective of the exclusion of poverty goes beyond material resources that are insufficient to cover topics such as human rights, security, refusal to vote, opportunities and violations of human dignity [4]. Terms such as disability, nonsense, exploitation, contrary values, inequality and underdevelopment are linked to this social exclusion [5]. Financial inclusion is an intervention strategy that seeks to overcome problems that prevent markets from operating favorably for the poor and underprivileged, especially in developing countries. It is the same with areas in the capital with many underprivileged people [6].

Improving the company's operational performance is the goal of a business organization regardless of the type of business being run. By using various performance measurements, an assessment of the effectiveness and efficiency of activities can be carried out according to the business process permit, objectives, and business strategies carried out. With performance measurements, the organization can carry out an evaluation process to determine whether the allocated resources are used, managed, and distributed properly following the goals set by the company. Financial inclusion through cooperatives is believed to be an effective way to reduce poverty or improve welfare [7]. 
Access to finance in term for the poor and disadvantaged, is a prerequisite for jobs, economic growth, poverty reduction and social engagement so can help for to have a bank account, save and save money, invest, protect their homes and facilitate them out of poverty [8]. Better access to credit for the poor allows them to lift themselves out of poverty by investing in their human capital and in micro-enterprises and can reducing aggregate poverty [9]. With an in-depth understanding of the relationships between financial inclusion, poverty (well-being), and income inequality, whether at the state, provincial, or district / city level, you will help policymakers design and implement programs that can scale up access to financial services the ultimate goal of fighting poverty, improving well-being and income equality. Additionally, financial inclusion through credit unions can reduce poverty and improve lower socioeconomic conditions.

There is no single definition of poverty that applies to all communities and regions over time because poverty is a complex phenomenon with many dimensions [10]. Financial inclusion must go through three dimensions: access, usage, and quality of financial services, but in the case of poverty, the dimensions of financial inclusion are supplemented by availability and impact (Amidzic, Massara, \& Mialou, 2014). Therefore, the measurement of financial inclusion should monitor the level of financial inclusion and deepen understanding of the factors related to financial inclusion (Serrao, Sequeira, \& Hans, 2012). These studies argue that financial inclusion is often measured across the five dimensions mentioned above. Access dimension refers to the physical presence and reach of financial services and the individual's ability to use financial products and services available at the point of service. The lack of financial service points was more dominant in rural areas than in urban areas. The quality dimension measures the relevance of financial products or services to the daily needs of financial consumers. Better results and perspectives need to be provided to address the anomalies in achieving full inclusion, the problem in people's use of frequencies and the quality of financial services provided to effectively meet needs. Therefore, the dimensions of use and quality in defining and measuring financial inclusion, in addition to simple access, are more useful for the analytical explanation of financial inclusion adopted by the research.

\subsection{Previous Research}

Previous studies related to the hypothesis development to answer the research problems can be seen in Table 1.

Table 1. Previous Studies

\begin{tabular}{cl}
\hline Author & \multicolumn{1}{c}{ Research Results } \\
\hline$[11]$ & $\begin{array}{l}\text { The results indicate that financial inclusion through cooperatives has a direct } \\
\text { and significant effect on rural development. Inclusive growth is part of a } \\
\text { broader chain of inclusive development, which means that its benefits must } \\
\text { reach all groups, especially women and children, minority groups, the } \\
\text { poorest and those at risk. made disasters. } \\
\text { The results indicate that financial inclusion through credit unions directly } \\
\text { and significantly affects community well-being. } \\
\text { This research shows that financial inclusion is the provision of financial } \\
\text { services at affordable costs to a wide segment of disadvantaged and low- } \\
\text { income groups, providing them with timely and adequate access to financial } \\
\text { products and services such as bank accounts, savings products, delivery and } \\
\text { payment, Insurance, Advice, Entrepreneurship and Microcredit and } \\
\text { Microfinance. Despite various initiatives, there are still many barriers to } \\
\text { financial inclusion. Therefore, public and private sector institutions must } \\
\text { work together to address these challenges and contribute to inclusive growth. }\end{array}$ \\
&
\end{tabular}




\begin{tabular}{|c|c|}
\hline Author & Research Results \\
\hline [14] & $\begin{array}{l}\text { Findings confirm that about } 38 \% \text { of respondents feel they do not have } \\
\text { enough income to open a bank account. In addition, moneylenders are still } \\
\text { the dominant source of rural finance, even though there are many banks in } \\
\text { rural areas. In short, although various steps have been taken to achieve } \\
\text { financial inclusion, the success is not significant enough. }\end{array}$ \\
\hline$[15]$ & $\begin{array}{l}\text { Inclusive growth is only possible through the right mechanisms that channel } \\
\text { all resources from top to bottom. The study was conducted in rural areas in } \\
\text { India because India has the largest rural population in the world. Financial } \\
\text { inclusion aims to provide Provide banking and financial services to all in a } \\
\text { fair, transparent and affordable way. }\end{array}$ \\
\hline [16] & $\begin{array}{l}\text { Financial inclusion in the form of financial services such as banking and } \\
\text { credit services provides great benefits for marginalized people with low } \\
\text { incomes. The financial inclusion services provided They include access to } \\
\text { savings, loans, insurance, payments and remittance services offered by the } \\
\text { formal financial system. Among the major financial services, risk } \\
\text { management or mitigation services dealing with economic shocks are } \\
\text { particularly relevant here. Such shocks can be income shocks due to adverse } \\
\text { weather conditions or natural disasters, or spending shocks due to health } \\
\text { emergencies or accidents, leading to high levels of unexpected spending. } \\
\text { This aspect of financial inclusion is very important in providing economic } \\
\text { security for individuals and families. }\end{array}$ \\
\hline
\end{tabular}

\subsection{Research Framework}

Financial inclusion is a solution that several countries have used to deal with the gap in people's economic level. When people have confidence in their abilities, it will increase financial inclusion (Mindra et al., 2017). Financial inclusion, which has three dimensions (access, usage, and quality), will determine whether formal financial services can be used optimally with a good financial understanding. The results further indicated that other controlled variables, such as age and gender, significantly affect people's usage of formal financial services (Mindra et al., 2017).

The effect of financial inclusion on community welfare through co-operatives remains undisputed . Therefore, the aforementioned gaps in the literature require current work and can help demonstrate the importance of co-operatives to policy makers and stakeholders.Financial inclusion is good and favors the poor, and encourages economic growth [17]. Financial inclusion benefits households with low incomes, which are more intensive in using basic financial services such as savings, credits, and insurances with the ultimate goal of increasing household financial independence [18]. Figure 1 presents the research framework:

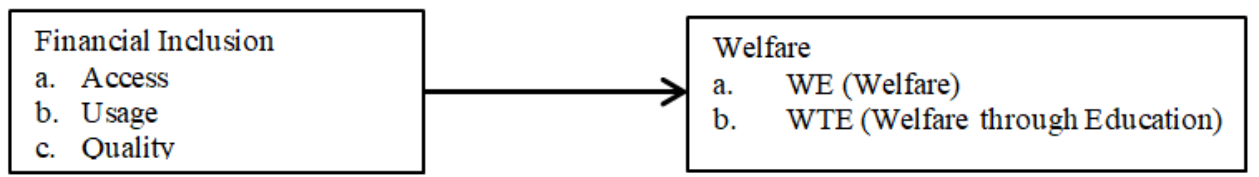

Fig. 1. Research Framework 
Jaiswal and Bhasin in their empirical study found that financial inclusion through cooperatives is key to empowering poor, disadvantaged and low-skilled rural families. By the financial inclusion mechanism, the establishment of cooperatives should increase the economic opportunities of poor and low-income people in a more positive direction, namely social progress, economic development and economic, social, political and legal empowerment [19], [20]. Based on the above description, the hypothesis can be formulated as follows:

$\mathrm{H}_{1}$ : Financial inclusion through cooperatives has a significant effect on community welfare viewed from access, usage, and service dimensions

Well (2012) in his research resulted in findings that the role of cooperatives has positive impact significantly with the advent of financial inclusion as the main driver of public policy in India. Despite significant improvements in all areas, cooperatives have failed to include large sectors of society in basic financial services, particularly the poor and vulnerable due to poor infrastructure, lack of awareness, poor quality of management, lack of strong personnel policies, inactive membership, and excessive reliance on government [7]. Based on the above description, the hypothesis can be formulated as follows:

$\mathrm{H}_{2}$ : Financial inclusion has a significant effect on community welfare when moderated by the education level viewed from access, usage, and service dimensions

\section{Research Method}

\subsection{Research Design}

This research used hypothesis testing to examine the effect of financial inclusion consisting of access, usage, and service dimensions on improving welfare moderated by the education level. The model used was Structural Equation Modeling (SEM) because the variable used was a latent variable (unobserved variable), so there were two equations, namely the structural model and the measurement model.

\subsection{Variables and Variable Measurement}

This research used two variables: the dependent variable (the community welfare), with or without being moderated by education level, and the independent variable (financial inclusion), which consists of three dimensions (access, usage, and service). The measurement of this research variable can be seen in Table 2 .

Table 2. Variable and Variable Measurement

\begin{tabular}{|c|c|c|}
\hline Variables & Name of Variable & Measurement \\
\hline Independent & Financial Inclusion & $\begin{array}{l}\text { 1. There is a road used to go to the nearest formal } \\
\text { financial services. } \\
\text { 2. The closest distance from the house to the nearest } \\
\text { bank is less than } 5 \mathrm{~km} \text {. } \\
\text { 3. The distance from the house to the nearest ATM is } \\
\text { not more than } 1 \mathrm{~km} \text {. } \\
\text { 4. There is a road to reach the nearest formal financial } \\
\text { 5ervices. }\end{array}$ \\
\hline
\end{tabular}




\begin{tabular}{|c|c|c|}
\hline Variables & Name of Variable & Measurement \\
\hline & & $\begin{array}{l}\text { financial (deposits, financing, insurances, and } \\
\text { payments/money transfers). } \\
\text { 6. I have a saving account to save on future expenses. } \\
\text { 7. I know the documents required to open a bank } \\
\text { account. } \\
\text { 8. I receive information quickly on the transactions } \\
\text { made. }\end{array}$ \\
\hline \multirow[t]{2}{*}{ Dependent } & $\begin{array}{l}\text { Welfare } 1 \text { (Community } \\
\text { welfare improvement) }\end{array}$ & $\begin{array}{l}\text { 1. Financial inclusion has increased the number of } \\
\text { electronic equipment (television, air } \\
\text { conditioner, computer, etc.) in my house. } \\
\text { 2. I consume more quality food than before e. } \\
\text { 3. My health is getting better by having quality } \\
\text { food. } \\
\text { 4. Financial inclusion has improved the quality of } \\
\text { flooring in my house. } \\
\text { 5. Financing program through cooperatives has a } \\
\text { positive effect on poverty reduction. } \\
\text { 6. Leaders say employees are not working } \\
\text { 7. My consumption level increased. } \\
\text { 8. Poverty reduction has become an important } \\
\text { goal of financial inclusion. } \\
\text { 9. I often buy basic necessities. } \\
\text { 10. My spending allocated on luxury goods has } \\
\text { increased. } \\
\text { 11. My spending on clothes has increased. }\end{array}$ \\
\hline & $\begin{array}{c}\text { Welfare } 2 \\
\text { (Community welfare } \\
\text { improvement moderated by } \\
\text { the education level) }\end{array}$ & $\begin{array}{l}\text { 1. Most of my family members have a minimum } \\
\text { educational background of Senior High School } \\
\text { graduates. } \\
\text { 2. The head of the family is educated enough to } \\
\text { guide family members. } \\
\text { 3. The financial crisis experienced by the family is } \\
\text { reduced through a better standard of living. } \\
\text { 4. Financial inclusion has reduced the crime rate } \\
\text { in my area. }\end{array}$ \\
\hline
\end{tabular}

\subsection{Data, Source, and Data Measurement}

Sampling employed purposive sampling. Samples were determined based on certain criteria. The selected samples were people living in Jakarta and its surrounding areas and never had more than two savings accounts at a bank. This research used primary data collected using a questionnaire. The questionnaire used a Likert scale of 1-5 (1 means strongly agree, 2 means agree, 3 means neutral, 4 means disagree, and 5 means strongly disagree).

The process of determining the number of samples is as follows:

a. The analysis units were the consumers of individual financial services in Jakarta and surrounding areas.

b. The samples were 139 members of the cooperative.

c. The design adopted the cross-sectional design and the alliance. 
d. Data were collected using a self-administered questionnaire.

The CB SEM analysis model was used to examine the relationship between the dependent variable and the independent variable.

\subsection{Analytical Tools}

This research used several analytical tools, including:

a) Research Instrument Testing

The instrument used to collect data must be of high quality. As such, a validity and reliability test was done on the instrument prior to data collection.

b) Validity Test

Indicators to measure a variable or dimension must be validated first. A validity test was carried out using factor loading criteria where the validity of an indicator depends on the number of research samples used. This research used a sample of 139 respondents, so the factor loading value was 0.50 . If the loading factor value is more than 0.50 , the instrument is said to be valid, and vice versa.

c) Reliability Test

A reliability test is carried out to test the consistency of answer from respondents. The reliability test uses the Cronbach alpha criteria, where a variable is reliable (reliable) if it has a Cronbach alpha value above or equal to 0.6 and vice versa. The results of validity and reliability tests are shown in Table 3. It can be seen that the financial inclusion variable consists of eight valid and reliable indicators. Of the 11 indicators, only eight were valid and reliable for the welfare variable, while the other three were not valid, namely indicators $9,10,11$. The welfare variable moderated by the education level, with four measurement indicators, had only two valid and reliable indicators, and indicators 3 and 4 must be omitted because they were not valid.

\subsection{Structural Equation Modeling (SEM)}

SEM was carried out as follows:

\section{a) Goodness-of-Fit test}

The goodness-of-fit test is a prerequisite test before testing the theoretical hypothesis to test whether the model follows the actual conditions. Testing the suitability of the model (goodness of fit) is based on the established measurement criteria [21], as shown in Table 3. The results of the processing indicate that from eight criteria, four criteria resulted in the fit model (RMSEA, IFI, CFI, and CMIN/DF), three criteria resulted in a marginal fit model (GFI, NFI, and TLI), and 1 criterion resulted in an unfit model (chi-square). Since most of the model fits were met, the theoretical hypothesis testing can be continued.

Table 3. Goodness-of-Fit Test Criteria

\begin{tabular}{ccccc}
\hline $\begin{array}{c}\text { Type of } \\
\text { Measurement }\end{array}$ & $\begin{array}{c}\text { The Goodness of Fit } \\
\text { Measurement }\end{array}$ & Expected value & $\begin{array}{c}\text { Resulted } \\
\text { Value }\end{array}$ & Conclusion \\
\hline Absolute Fit Index & $\chi^{2}-$ Chi-square & $\begin{array}{c}\text { Expected to be a } \\
\text { small value } \\
\end{array}$ & 228.56 & \\
& p-value & $\geq 0.05$ & 0.000 & Poor fit \\
GFI & $\geq 0.90$ & 0.822 & Marginal fit \\
\hline
\end{tabular}




\begin{tabular}{ccccc}
\hline $\begin{array}{c}\text { Type of } \\
\text { Measurement }\end{array}$ & $\begin{array}{c}\text { The Goodness of Fit } \\
\text { Measurement }\end{array}$ & Expected value & $\begin{array}{c}\text { Resulted } \\
\text { Value }\end{array}$ & Conclusion \\
\hline \multirow{2}{*}{ Incremental Fit Index } & RMSEA & $\leq 0.10$ & 0.098 & Fit \\
& IFI & $\geq 0.90$ & 0.906 & Fit \\
& NFI & $\geq 0.90$ & 0.846 & Marginal fit \\
& TLI & $\geq 0.90$ & 0.879 & Marginal fit \\
Parsimonious Fit Index & CFI & $\geq 0.90$ & 0.904 & Fit \\
\hline
\end{tabular}

Source: Ghazali [21]

\section{b) Descriptive Analysis}

Descriptive analysis was used to view information from participant profiles. This analysis was also used as a parameter to see the uniformity of participant profiles to ensure that samples were balanced in terms of community groups or people who lived in the city center and on the outskirts of the city.

\section{c) Research Hypothesis Testing}

The hypothesis testing of this research was conducted using Structural Equation Modeling (SEM) because the existing data were perceptions and ordinal scales.

\section{Results and Discussion}

\subsection{Descriptive Statistics of Research Variables}

\subsubsection{Descriptive Statistics of the Financial Inclusion Variable}

The descriptive statistics of financial inclusion are shown in Table 4. Overall, the respondents responded positively to financial inclusion, as indicated by the average value of respondents' answers of 4.105. The standard deviation value of 0.782 indicates the variation of respondents' answers is in the range of answer choices between 3 to 5. Respondents also showed a good response to financial inclusion dimensions (access, usage, and service), where the three dimensions have an average value of more than 4 . The lowest average answer value is the access dimension (4.046), while the highest average answer value is the service dimension (4.212). The community welfare improvement variable has an average value of 3.736. The standard deviation value of 0.779 indicates respondents' answers were in the range of answer choices between 3 to 5 . The response on the eight indicators also shows a fairly good response. The lowest score is indicator 4, with an average score of 3.547 , while the highest is indicator 3, with an average score of 4.007 .

Table 4. Descriptive Statistics of Financial Inclusion

\begin{tabular}{cccccc}
\hline No. & Statement & Mean & Std Deviation & Minimum & Maximum \\
\hline 1. & Access & 4.046 & 0.832 & 1.00 & 5.00 \\
2. & Usage & 4.057 & 0.894 & 1.00 & 5.00 \\
3. & Service & 4.212 & 0.872 & 1.00 & 5.00 \\
& Financial Inclusion & 4.105 & 0.782 & 1.00 & 5.00 \\
\hline
\end{tabular}

Source: Questionnaire data processed with SPSS 


\subsubsection{Descriptive Statistics of Community Welfare Improvement}

The descriptive statistics of community welfare improvement are shown in Table 5 . Overall, the respondents gave a fairly good response.

Table 5. Descriptive Statistics of Community Welfare Improvement

\begin{tabular}{|c|c|c|c|c|c|}
\hline No. & Statement & Mean & $\begin{array}{c}\text { Std } \\
\text { Deviation }\end{array}$ & Minimum & Maximum \\
\hline 1. & $\begin{array}{l}\text { Financial inclusion has increased the number } \\
\text { of electronic equipment (television, air } \\
\text { conditioner, computer, etc.) in my house. }\end{array}$ & 3.712 & 1.065 & 1.00 & 5.00 \\
\hline 2. & I consume more quality food than before. & 3.640 & 0.963 & 1.00 & 5.00 \\
\hline 3. & $\begin{array}{l}\text { My health is getting better by having quality } \\
\text { food. }\end{array}$ & 4.007 & 0.855 & 1.00 & 5.00 \\
\hline 4. & $\begin{array}{l}\text { Financial inclusion has improved the quality } \\
\text { of flooring in my house. }\end{array}$ & 3.547 & 1.051 & 1.00 & 5.00 \\
\hline 5. & $\begin{array}{l}\text { Financing program through cooperatives has } \\
\text { a positive effect on poverty reduction. }\end{array}$ & 3.777 & 1.057 & 1.00 & 5.00 \\
\hline 6. & $\begin{array}{l}\text { Leaders say employees are not working } \\
\text { efficiently. }\end{array}$ & 3.604 & 0.953 & 2.00 & 5.00 \\
\hline 7. & My consumption level increased & 3.662 & 1.189 & 1.00 & 5.00 \\
\hline \multirow[t]{2}{*}{8.} & $\begin{array}{l}\text { Poverty reduction has become an important } \\
\text { goal of financial inclusion. }\end{array}$ & 3.935 & 0.918 & 1.00 & 5.00 \\
\hline & Community Welfare Improvement & 3.736 & 0.779 & 1.75 & 5.00 \\
\hline
\end{tabular}

\subsubsection{Descriptive Statistics of Community Welfare Improvement Moderated by the Education Level Variable}

The results of the descriptive statistics of the community welfare improvement moderated by the education level variable are shown in Table 6. The respondents generally responded fairly well to the community welfare improvement variable moderated by the education level variable. The standard deviation of 0.893 shows that the respondents' answers for the variable are mostly in the range of answer choices between 3 to 5. From the responses of each measurement indicator, the largest contribution is indicator 2 (the head of the family is well educated to guide family members), with an average score of 3.964. On the other hand, the lowest contribution is indicator 1 (most of my family members have a minimum educational background of senior high school graduates) with an average score of 3.755.

Table 6. Descriptive Statistics of Community Welfare Improvement Moderated by the Education Level Variable

\begin{tabular}{llcccc}
\hline No. & \multicolumn{1}{c}{ Statement } & Mean & $\begin{array}{c}\text { Std } \\
\text { Deviation }\end{array}$ & Minimum & Maximum \\
\hline $1 . \quad \begin{array}{l}\text { Most of my family members have a } \\
\text { minimum educational background of senior } \\
\text { high school graduates. }\end{array}$ & 3.755 & 1.172 & 1.00 & 5.00 \\
2. & & & \\
& $\begin{array}{l}\text { The head of the family is well educated to } \\
\text { guide family members. } \\
\text { Community Welfare Improvement } \\
\text { Moderated By the Education Level }\end{array}$ & 3.964 & 0.904 & 2.00 & 5.00 \\
$\quad$ Source: Questionnaire data processed with SPSS
\end{tabular}

Source: Questionnaire data processed with SPSS 


\subsubsection{Analysis of Findings}

This research used SEM as an analytical tool to test the proposed research hypothesis. The hypothesis testing is as follows:

a) Hypothesis $1 \mathrm{a}$

Hypothesis 1a examined the effect of financial inclusion through cooperatives on community welfare from the access dimension. The estimated coefficient value of 0.0019 indicates that increasing financial inclusion through cooperatives from the access dimension will increase community welfare, and conversely, decreasing financial inclusion through cooperatives from the access dimension will reduce community welfare. The p-value is $0.4974>0.05$, which means Ho is accepted. Thus, financial inclusion through cooperatives from the access dimension positively affects community welfare.

b) Hypothesis $1 \mathrm{~b}$

Hypothesis $1 \mathrm{~b}$ examined the effect of financial inclusion through cooperatives on community welfare from the usage dimension. The estimated coefficient value of 2.2322 indicates that increasing financial inclusion through cooperatives from the usage dimension will increase community welfare, and conversely, decreasing financial inclusion through cooperatives from the usage dimension will reduce community welfare. The p-value is $0.4974>0.05$, and the t-value of 4.1442 , which means Ho is accepted. Thus, financial inclusion through cooperatives from the usage dimension positively affects community welfare.

c) Hypothesis 1c

Hypothesis 1c examined the effect of financial inclusion through cooperatives on community welfare from the service dimension. The estimated coefficient value of 1.3183 indicates that increasing financial inclusion through cooperatives from the service dimension will decrease community welfare, and conversely, decreasing financial inclusion through cooperatives from the service dimension will increase community welfare. Thus, financial inclusion through cooperatives from the service dimension negatively affects community welfare. Table 7 presents the result of hypothesis test.

Table 7. Results of Hypothesis Testing

\begin{tabular}{|c|c|c|c|c|c|}
\hline & Description of Hypothesis & Estimate & C.R. & p-value & Conclusion \\
\hline $\mathrm{H}_{1 \mathrm{a}}$ & $\begin{array}{l}\text { Financial inclusion through cooperatives } \\
\text { from the access dimension has a } \\
\text { significant effect on community welfare. }\end{array}$ & 0.0019 & .0066 & 0.4974 & $\begin{array}{l}\text { Hypothesis } \\
\text { is not } \\
\text { supported }\end{array}$ \\
\hline $\mathrm{H}_{1 b}$ & $\begin{array}{l}\text { Financial inclusion through cooperatives } \\
\text { from the usage dimension has a } \\
\text { significant effect on community welfare. }\end{array}$ & 2.2322 & 4.1442 & 0,000 & $\begin{array}{l}\text { Hypothesis } \\
\text { is } \\
\text { supported }\end{array}$ \\
\hline $\mathrm{H}_{1 \mathrm{c}}$ & $\begin{array}{l}\text { Financial inclusion through cooperatives } \\
\text { from the service dimension has a } \\
\text { significant effect on community welfare. }\end{array}$ & -1.3183 & $\begin{array}{c}- \\
2.7518\end{array}$ & 0.0029 & $\begin{array}{l}\text { Hypothesis } \\
\text { is not } \\
\text { supported }\end{array}$ \\
\hline $\mathrm{H}_{2 \mathrm{a}}$ & $\begin{array}{l}\text { Financial inclusion through cooperatives } \\
\text { from the access dimension has a } \\
\text { significant effect on community welfare } \\
\text { moderated by the education level. }\end{array}$ & 0.1590 & 0.8207 & 0.2059 & $\begin{array}{l}\text { Hypothesis } \\
\text { is not } \\
\text { supported }\end{array}$ \\
\hline $\mathrm{H}_{2 b}$ & $\begin{array}{l}\text { Financial inclusion through cooperatives } \\
\text { from the usage dimension has a }\end{array}$ & 0.3075 & 3.1989 & 0.0007 & $\begin{array}{l}\text { Hypothesis } \\
\text { is }\end{array}$ \\
\hline
\end{tabular}




\begin{tabular}{|c|c|c|c|c|c|}
\hline & Description of Hypothesis & Estimate & C.R. & p-value & Conclusion \\
\hline & $\begin{array}{l}\text { significant effect on community welfare } \\
\text { moderated by the education level. }\end{array}$ & & & & supported \\
\hline $\mathrm{H}_{2 \mathrm{c}}$ & $\begin{array}{l}\text { Financial inclusion through cooperatives } \\
\text { from the service dimension has a } \\
\text { significant effect on community welfare } \\
\text { moderated by the education level. }\end{array}$ & -0.3171 & $1 . \overline{1411}$ & 0.1269 & $\begin{array}{l}\text { Hypothesis } \\
\text { is not } \\
\text { supported }\end{array}$ \\
\hline
\end{tabular}

Source: Results of Data Processing

d) Hypothesis $2 \mathrm{a}$

Hypothesis 2 a examined the effect of financial inclusion through cooperatives on community welfare from the access dimension moderated by the education level. The estimated coefficient value of 0.1590 indicates that increasing financial inclusion through cooperatives from the usage dimension will increase community welfare when moderated by the education level, and vice versa. The $p$-value is $0.2059>0.05$, and the t-value of 0.8207 , which means Ho is accepted. Thus, financial inclusion through cooperatives from the usage dimension positively affects community welfare when mediated by the education level.

e) Hypothesis $2 b$

Hypothesis $2 b$ examined the effect of financial inclusion through cooperatives on community welfare from the usage dimension moderated by the education level. The estimated coefficient value of 0.3075 indicates that increasing financial inclusion through cooperatives from the usage dimension will increase community welfare when moderated by the education level, and vice versa. The $p$-value is $0.000<0.05$, and the t-value of 3.1989, which means Ho is rejected and $\mathrm{Ha}$ is accepted. Thus, financial inclusion through cooperatives from the usage dimension does not affect community welfare when mediated by the education level.

f) Hypothesis $2 \mathrm{c}$

Hypothesis 2c examined the effect of financial inclusion through cooperatives on community welfare from the service dimension moderated by the education level. The estimated coefficient value of -0.3171 indicates that increasing financial inclusion through cooperatives from the usage dimension will decrease community welfare when moderated by the education level, and vice versa. The $p$-value is 0.2059 $>0.05$, and the t-value of 0.8207 , which means Ho is accepted. Thus, financial inclusion through cooperatives from the service dimension does not affect community welfare when mediated by the education level.

\subsection{Discussion}

The findings show that access and service dimensions are not proven to affect the community welfare, either with or without being moderated by education level-supported by the scatter plot results from historical data as shown in Figure 2. Figure 2 shows no positive relationship pattern between access and community welfare or between service and community welfare. These findings indicate that access is an inhibiting factor of cooperative members in improving community welfare. Financial literacy for the access dimension has been a problem for cooperativedelays in banking information update - for example, cooperative members do not know that the new ATM functions not only to withdraw but also to save money. These factors have caused cooperative members to not being able to save their 
money because the bank and the ATM are far from their homes, the road to those facilities is not in good condition, and they do not know the latest feature available. This situation has led to suboptimal financial inclusion that finally cooperative members cannot significantly improve their welfare. The service dimension of financial inclusion is the other factor hindering an increase in community welfare. Cooperative members do not get updates on banking services, such as the requirements to open a bank account.

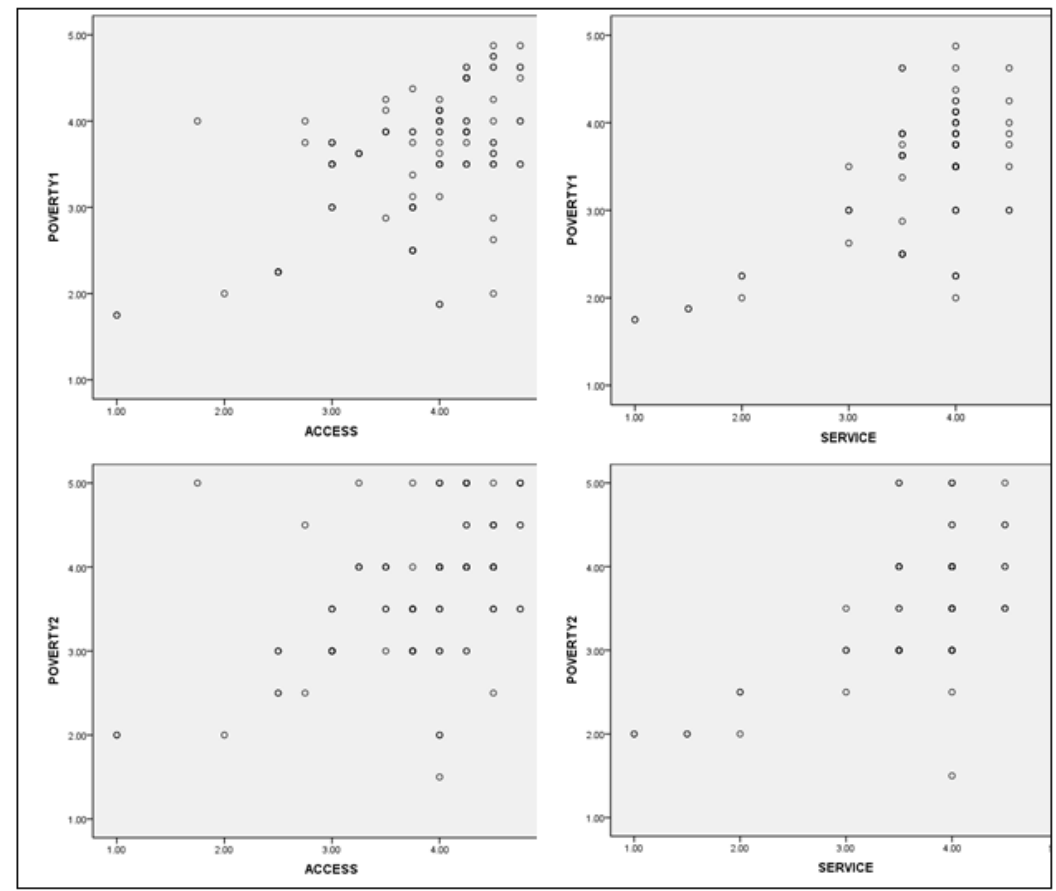

Fig 2. Scatter Plot of Access and Service Dimensions on Welfare 1 and Welfare 2

On the other hand, the scatter plot for the relationship between usage dimension and the level of community welfare shows a positive relationship pattern, as shown in Figure 3.

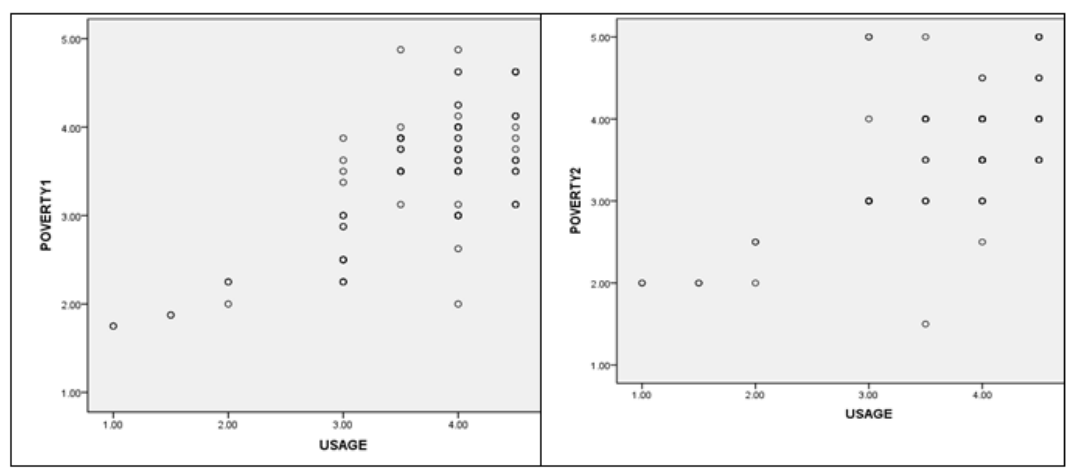

Fig 3. Scatter Plot of Usage Dimension On Welfare 1 and Welfare 2 
Members because they cannot get good road access to the bank or the ATM, not to mention that the bank and the ATM are located far away from their homes. The low access to financial inclusion has caused.

\section{Conclusion and Suggestion}

\subsection{Conclusions}

From the research findings described above, the following conclusions can be drawn:

1. Access dimension of financial inclusion is not proven to affect community welfare (savings and loan cooperative members in Jakarta and its surrounding areas).

2. Usage dimension of financial inclusion is proven to affect community welfare (savings and loan cooperative members in Jakarta and its surrounding areas).

3. Service dimension of financial inclusion is not proven to affect community welfare (savings and loan cooperative members in Jakarta and its surrounding areas).

4. Access dimension of financial inclusion is not proven to affect community welfare (savings and loan cooperative members in Jakarta and its surrounding areas) when moderated by the education level.

5. Usage dimension of financial inclusion is proven to affect community welfare (savings and loan cooperative members in Jakarta and its surrounding areas) when moderated by the education level.

6. Service dimension of financial inclusion is not proven to affect community welfare (savings and loan cooperative members in Jakarta and its surrounding areas) when moderated by education level.

\subsection{Suggestions}

Based on findings, discussion, and conclusions, the following suggestions are presented:

1. Increasing financial inclusion for cooperative members, especially services, is an important factor in improving community welfare. It can be done through more intense socialization activities related to services provided by banks, so that cooperative members can use the information to increase financial inclusion. In the end, this is expected to have a significant effect on the welfare of cooperative members.

2. Access to banking is determined by an external factor or the banking service itself. Thus, access, in this case, can be built if cooperative members already understand the services provided by banks and experience the benefits. The problem related to access can be minimized if the members understand the importance of financial literacy. The distance to the ATM and the bank will not be a problem if cooperative members already experience the benefits of becoming bank customers.

\section{References}

[1] World Bank, Global Financial Development Report 2014: Financial Inclusion. Washington: World Bank, 2014.

[2] G. Comparato, "The rationales of financial inclusion in the changing European private law," Eur. Rev. Contract Law, vol. 11, no. 1, pp. 22-45, 2015.

[3] G. W. Ssonko, "The role of mobile money services in enhancing financial inclusion in 
Uganda," Bank Uganda, 2010.

[4] C. Stilwell, "Public Libraries and Social Inclusion: An Update from South Africa," in Perspectives on Libraries as Institutions of Human Rights and Social Justice, vol. 41, Emerald Group Publishing Limited, 2016, pp. 119-146.

[5] C. Stilwell, "Poverty, social exclusion, and the potential of South African public libraries and community centres," Libri, pp. 50-66, 2011.

[6] J. Aduda and E. Kalunda, "Financial inclusion and financial sector stability with reference to Kenya: A review of literature," J. Appl. Financ. Bank., vol. 2, no. 6, p. 95, 2012.

[7] P. Lakshmi and S. Visalakshmi, "Impact of cooperatives in financial inclusion \& comprehensive development," J. Financ. Econ., vol. 1, no. 3, pp. 49-53, 2013.

[8] K. C. Chakrabarty, "Banking and beyond: new challenges before Indian financial system," RBI Mon. Bull. April, 2011.

[9] C. Chibango, "Mobile money revolution: An opportunity for financial inclusion in Africa," Int. J. Humanit. Soc. Stud., vol. 2, no. 2, pp. 59-67, 2014.

[10] C. Luo, "Economic growth, inequality and Welfare in rural China," Econ. Res., pp. 1527, 2012.

[11] T. Lal, "Measuring Impact of Financial Inclusion on Rural Development through Cooperatives," Int. J. Soc. Econ., vol. 46, no. 3, pp. 352-376, 2019, doi: 10.1108/IJSE02-2018-0057.

[12] T. Lal, "Impact of Financial Inclusion on Poverty Alleviation through Cooperative Banks," Int. J. Soc. Econ., vol. 45, no. 5, pp. 808-828, 2018, doi: 10.1108/IJSE-052017-0194.

[13] H. N. Archana, "Financial Inclusion - Role of Institutions," Innov. J. Bus. Manag., vol. 2, no. 4, pp. 44-48, 2013.

[14] S. K. Chattopadhyay, "Financial Inclusion in India: A case-study of West Bengal," 34629, 2011.

[15] C. Paramasivan and V. Ganeshkumar, "Overview of Financial Inclusion in Bangladesh," Int. J. Manag. Dev. Stud., vol. 2, no. 3, pp. 1-7, 2013, doi: $10.9780 / 23197943$.

[16] V. Kelkar, "Financial Inclusion for Inclusive Growth," ASCI J. Manag., vol. 39, no. 1, pp. 55-68, 2010.

[17] B. Sarath Chandra and T. Manju, "Financial inclusion strategies for inclusive growth in India," MPRA Pap. No. 33569, Univ. Libr. Munich, 2010.

[18] V. Kumar, "Financial inclusion and Welfare eradication; a theoretical perspective," Int. J. Eng. Manag. Sci., pp. 170-175, 2015.

[19] B. Jaiswal and S. Bhasin, "Role of cooperative banks in financial inclusion for inclusive growth in India," Int. J. Manag. Soc. Sci. Res., pp. 6-18, 2015.

[20] S. Mondal, "Financial inclusion: A step towards eradicate poverty," Am. J. Theor. Appl. Bus., vol. 1, no. 1, pp. 21-26, 2015.

[21] I. Ghozali, Aplikasi Analisis Multivariete Dengan Program IBM SPSS. Semarang: Badan Penerbit Univeristas Diponegoro, 2011. 